\title{
Correction to: Supercooling preservation technology in food and biological samples: a review focused on electric and magnetic field applications
}

\author{
Taiyoung Kang ${ }^{1} \cdot$ Youngsang $\mathrm{You}^{2} \cdot$ Soojin $\mathrm{Jun}^{2} \mathbb{C}$
}

(C) The Author(s) 2020

\section{Food Sci Biotechnol (2020) 29(3):303-321 https://doi.org/10.1007/s10068-020-00750-6}

The article "Supercooling preservation technology in food and biological samples: a review focused on electric and magnetic field applications", written by Taiyoung Kang, Youngsang You and Soojin Jun, was originally published Online First without Open Access. After publication in volume 29, issue 3, pages 303-321 the author decided to opt for Open Choice and to make the article an Open Access publication. Therefore, the copyright of the article has been changed to @ The Author(s) 2020 and the article is forthwith distributed under the terms of the Creative Commons Attribution 4.0 International License (http://creativecommons. org/licenses/by/4.0/), which permits use, duplication, adaptation, distribution and reproduction in any medium or format, as long as you give appropriate credit to the original author(s) and the source, provide a link to the Creative Commons license, and indicate if changes were made.

The original article has been corrected.

The original article can be found online at https:// doi.org/10.1007/s10068-020-00750-6.

Soojin Jun

soojin@hawaii.edu

Taiyoung Kang

taiyoung@hawaii.edu

Youngsang You

yyou7@hawaii.edu

1 Department of Molecular Biosciences and Bioengineering, University of Hawaii at Manoa, Honolulu, HI 96822, USA

2 Department of Human Nutrition, Food and Animal Sciences, University of Hawaii at Manoa, Honolulu, HI 96822, USA
Open Access This article is licensed under a Creative Commons Attribution 4.0 International License, which permits use, sharing, adaptation, distribution and reproduction in any medium or format, as long as you give appropriate credit to the original author(s) and the source, provide a link to the Creative Commons licence, and indicate if changes were made. The images or other third party material in this article are included in the article's Creative Commons licence, unless indicated otherwise in a credit line to the material. If material is not included in the article's Creative Commons licence and your intended use is not permitted by statutory regulation or exceeds the permitted use, you will need to obtain permission directly from the copyright holder. To view a copy of this licence, visit http://creativecommons. org/licenses/by/4.0/.

Publisher's Note Springer Nature remains neutral with regard to jurisdictional claims in published maps and institutional affiliations. 